\title{
Water Security and Climate Change: The Need for Adaptive Governance
}

\section{T Honkonen*}

\section{P.E.R}

Pioneer in peer-reviewed, open access online law publications.

Author

Tuula Honkonen

Affiliation

University of Eastern Finland, Finland.

Email

tuula.h.honkonen@gmail.com

Date published

5 January 2017

Editor Mr CB Soyapi

Co-Editor Ms T Honkonen

How to cite this article

Honkonen T "Water Security and Climate Change: The Need for Adaptive Governance." PER / PELJ 2017(20) - DOI

http://dx.doi.org/10.17159/17273781/2017/v20i0a1651

Copyright

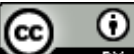

DOI

http://dx.doi.org/10.17159/1727-

3781/2017/v20i0a1651

\begin{abstract}
Climate change will bring about unprecedented economic, social and environmental effects, which require both the mitigation of greenhouse gas emissions and adaptation to its adverse effects. Water is the main element through which the impacts of climate change will be felt. Climate change results in increased uncertainties, complexities, stress and potential for conflicts within water management, both among and within states. New forms of governance are needed if the world is to respond to the need to adapt to changes in freshwater supply and to manage water security risks.
\end{abstract}

This paper suggests that adaptive governance should to be main-streamed into all water regulation to ensure the availability of and access to safe water resources and to prevent waterrelated conflicts. The paper discusses the concept of water security in the context of climate change, the threats that climate change poses to water security, and the concept and implications of adaptive governance as a possible solution.

The application of adaptive governance requires a certain degree of institutional and normative flexibility, instruments and institutions that can respond and adapt to changes and manage the level of uncertainty associated with the impacts of climate change. The governance institutions, methods and instruments should be responsive to new information and different kinds of uncertainties, while reflecting the vulnerabilities, capacities, needs and priorities of both societies and ecosystems in the face of climate change. Water security risks could be reduced by increased hydrosolidarity among states, which would present the challenges posed by climate change on water governance and security as primarily an opportunity for new forms of cooperation.

\section{Keywords}

Climate change; freshwater resources; water security; adaptive governance. 


\section{Introduction}

Climate change is in many ways the most pressing challenge that humanity faces today. Future climate changes, risks and impacts will be severe: increased global mean temperatures, extreme precipitation events, warmed and acidified oceans, global mean sea level rises, and unevenly distributed risks to natural and human systems. ${ }^{1}$

The impacts of climate change are being felt already in all parts of the world, and the detrimental effects are projected to increase substantially in the years to come. ${ }^{2}$ The economic, social and environmental effects of climate change have no precedent in history, and it is clear that both mitigation and adaptation actions are needed in the face of the dramatic changes that life on Earth is going to experience due to human-induced changes in climate.

Mitigation and adaptation are also the two main pillars of the international climate change regime: the UN Framework Convention on Climate Change, the Kyoto Protocol and the recently adopted Paris Agreement. The international regime has established a number of adaptation frameworks, obligations and activities for the Parties. ${ }^{3}$ The Paris Agreement strengthens the adaptation efforts, for instance by the adaptation goal of "enhancing adaptive capacity, strengthening resilience and reducing vulnerability to climate change".

Climate change has been said to be largely water change. Climate change affects all aspects of the water cycle, and water is the main way through which the impacts of climate change will be felt. ${ }^{4}$ There is no escaping the fact that water is a fundamental element of the climate system. Climate change will ultimately come down to changes in the timing of water (when water is delivered), and the quantity (how much water is available) and quality of the water resources. ${ }^{5}$ These changes are apt to produce risks to water security. Water security is presently generally perceived as one of the main objectives of water resources management at all levels. ${ }^{6}$ The

* Tuula Honkonen. LLM (London School of Economics and Political Science) DSc Environmental Law (University of Joensuu). Post-doc Researcher, University of Eastern Finland. Email: tuula.h.honkonen@gmail.com. The author participated in the research project "Legal framework to promote water security" (WATSEC), financed by the Academy of Finland (268151).

IPCC Climate Change 2014 8-16.

IPCC Climate Change 2014 8-16.

For a summary, see UN 2014 http://unfccc.int/adaptation/items/4159.php.

OECD Water and Climate Change Adaptation 18.

Cook et al Shifting Course 3.

See eg Wouters Water Security; and Mirumachi Transboundary Water Security. 
projected (negative) impacts of climate change on the wide variety of functions and uses of water and on the related risks to water security from the international to the national level necessitate the establishment of new modes of governance. Water regulation needs to be responsive to conditions of high complexity and uncertainty exacerbated by climatic changes in all parts of the world. ${ }^{7}$ Traditionally, water regulation has strongly relied on historical and existing uses, ${ }^{8}$ which makes the legal mechanisms (for instance, on water allocation) particularly vulnerable to future changes in water flows. This applies to both the national and the transboundary level of water governance.

This paper suggests that the concept of adaptive governance needs to be mainstreamed into all water regulation to ensure the availability of and access to safe water resources and to prevent water-related conflicts. Adaptive governance is understood as referring to adaptation policies and measures that support the adaptive capacity of society, often with an iterative approach to policy-making, stressing flexibility of the regulatory instruments. ${ }^{9}$ The main difficulty from a legal perspective with adaptive governance is its potential to clash with the ideal of legal certainty of regulation. Conversely, uncertainties and changing circumstances, the main consequences of climate change, render stationary legal instruments largely meaningless.

The main research questions of this paper are: What is water security that also includes a climate change perspective? What threats does climate change pose to water security? How do we account for water security risks posed by climate change? How do we understand the concept of adaptive governance, and what are its implications within the present context? And how could adaptive governance be used to manage the impacts of climate change on freshwater resources and to reduce water insecurity? These questions are examined in this paper from a legal and regulatory perspective and on a general governance level, with no specific geographical context implied. The purpose of the paper is to provide ideas and tools for policy-makers and analyzers to account for water security risks when climate change policies are developed, and to take into account climate change aspects in the development of freshwater governance. What is certain is that no instrument of water regulation can ignore the fact that climate change is going to alter the water system and that the existing

7 See eg Bakker and Morinville 2013 Phil Trans R Soc A; and Sadoff and Muller Water Management.

$8 \quad$ See eg Sanchez and Roberts Transboundary Water Governance 11.

9 See ch 5.1 in this paper. 
management instruments will be forced to respond to these changes sooner or later.

This paper is structured as follows. First, after the introduction, a short review is given of the concept of water security. Next, the anticipated effects of climate change on freshwater resources will be briefly examined and the concomitant risks to water security will be mapped out. In the light of these, the need to adapt will become clear. In the following part of the paper, a range of governance challenges of adaptation to account for the risks posed by climate change to water security will be briefly examined. After that, the need for adaptive governance of freshwater in the face of climate change will be discussed, in depth and the paper will end with some concluding remarks.

\title{
2 The concept of water security
}

Water security as a concept has received increasing attention in both scholarly writings and practical policy-making in recent years. Numerous definitions and interpretations of the concept exist. ${ }^{10}$ According to the United Nations Water Security Initiative, the concept may be defined as

\begin{abstract}
... the capacity of a population to safeguard sustainable access to adequate quantities of acceptable quality water for sustaining livelihoods, human wellbeing, and socio-economic development, for ensuring protection against water-borne pollution and water-related disasters, and for preserving ecosystems in a climate of peace and political stability. ${ }^{11}$
\end{abstract}

A rather similar definition was provided in 2009 by Sadoff and Muller, who understand water security to be

... the reliable availability of an acceptable quantity and quality of water for health, livelihoods and production, coupled with an acceptable level of waterrelated risks. ${ }^{12}$

A third example is provided in the Ministerial Declaration of the Second World Water Forum, adopted in 2000: water security in the 21st century means

[e]nsuring that freshwater, coastal and related ecosystems are protected and improved; that sustainable development and political stability are promoted, that every person has access to enough safe water at an affordable cost to

10 For a summary, see eg Cook and Bakker 2012 Global Environmental Change; Lautze and Manthrithilake 2012 Natural Resources Forum.

11 UN Water Water Security 1.

12 Sadoff and Muller Water Management 11. 
lead a healthy and productive life and that the vulnerable are protected from the risks of water-related hazards. ${ }^{13}$

Common to these and most other definitions of water security is their multidimensionality. They connect water security mainly to the right of people to an adequate quantity and quality of freshwater, with the aim of preventing conflicts, but tolerating a reasonable level of water-related risks, and sometimes also emphasising the protection of water-dependent ecosystems.

Wouters et $\mathrm{a}^{14}$ have distinguished between three core issues central to the concept of water security. These are the availability of water, access to water, and conflict over water use. A slightly more nuanced view is provided by Mason and Calow, ${ }^{15}$ who argue that an expansive and inclusive framing of water security should: 1) look beyond immediate physical availability; 2) address variability and risk; 3) have a human focus; 4) acknowledge environmental needs; and 5) manage competition and conflict. These qualities actually form quite a robust basis on which water resources governance could be constructed with a view to addressing risks to water security.

What often stands out from the different definitions of water security are the different framings within which the concept is presented: a dichotomy between human needs and vulnerability on the one hand, and sustainability and the protection of ecosystems on the other. It is not necessary, however, that these different perspectives should be seen as contrdictory. Mason and Calow ${ }^{16}$ have posited that their model of water security has the potential to synthesise developmental and environmental objectives. Nevertheless, it is also acknowledged that in reality those objectives can often appear to be in competition and presenting the need for trade-offs rather than opportunities for synthesis. ${ }^{17}$

In addition to the distinction between the human and ecosystem approaches to water security, the concept may be framed from an individual or a state security perspective. The former emphasizes a human rights approach

13 Ministerial Declaration of The Hague on Water Security in the 21st Century (2000).

14 Wouters, Vinogradov and Magsig 2009 YbIEL 106.

15 Mason and Calow Water Security 19.

16 "A broad conception of water security should therefore allow for recognition of our universal dependency on water as a fundamental form of natural capital, in a way that recognises both an environmental dimension (protecting the resource for our own and future generations) and a developmental one (providing access to sufficient water to permit all to fulfil their capabilities)." Mason and Calow Water Security 1. Mason and Calow Water Security 4. 
within states ${ }^{18}$ while the latter conceives of water security mainly as a potential source of conflicts between states. These conflicts do not necessarily lead to or even threaten to lead to military action and war, but are more focused on (the potential of) political conflicts among states, often in relation to shared water resources. The present paper has adopted a multifaceted outlook on water security, acknowledging the human rights approach but slightly emphasising a state-centred view, in line with the general governance perspective of the paper.

\section{Risks posed by climate change to water and water security}

First of all, it is important to note the fact that change is constant in freshwater systems. These systems are not static, even in the absence of the effects of climatic change. To be sure, there is routine seasonal variability, which is usually also anticipated in the relevant regulatory arrangements and management policies. Within this context, the particular impacts due to climate change may sometimes be difficult to perceive and draw attention to. ${ }^{19}$

According to the Intergovernmental Panel on Climate Change (IPCC), freshwater-related risks of climate change increase significantly with increasing greenhouse gas concentrations. ${ }^{20}$ Climate change is predicted to reduce renewable surface water and groundwater resources significantly in most dry subtropical regions, whereas in regions with snowfall, climate change has already altered observed streamflow seasonality. ${ }^{21}$ Moreover, by the end of the 21 st century climate change is likely to increase the frequency of meteorological droughts (less rainfall) and agricultural droughts (less soil moisture) in regions that are presently dry. ${ }^{22}$ Climate change is also affecting the seasonal variability of water flows, groundwater and nutrient flows. ${ }^{23}$

18 Under the International Covenant on Economic, Social and Cultural Rights (1967), the Committee has given some weight to the effects of climate change in relation to the human rights that the Covenant protects. See eg Orellana et al Climate Change. The United Nations General Assembly declared the right to water as a human right in 2010 (The Human Right to Water and Sanitation GA Res 64/292, UN Doc A/RES/64/292 (2010)). Also see eg OHCHR Understanding Human Rights and Climate Change.

19 See also McCaffrey 2003 Natural Resources Forum 157.

20 See generally Jiménez Cisneros et al "Freshwater Resources".

21 Jiménez Cisneros et al "Freshwater Resources" 232.

22 Jiménez Cisneros et al "Freshwater Resources" 232.

23 See generally Jiménez Cisneros et al "Freshwater Resources". 
Science has been able to provide a basic understanding of how the hydrological cycle will change at the global and regional levels and has shown that the impacts of climate change on water will be dramatic. ${ }^{24}$ However, it is also likely that unforeseen changes and circumstances will emerge in relation to freshwater systems. These will put the water systems and their management regimes to the test. Resilience and adaptive capacity will become key qualities in the process and the relevance of security will simultaneously become greater. It has been argued that when the rate of change to a water system exceeds its capacity to adapt, the myriad connections to overall security and stability soon become evident. ${ }^{25}$

It has become clear that the impacts of climate change will not be on the same scale in every freshwater basin in the world. Even at the level of an individual basin the effects of climate change will vary, depending on the location. In general, the effects of climate change on freshwater resources will depend on numerous factors, including geography, the (human) demand for water and its utilisation, existing management mechanisms and governance structures and institutions, and the resilience (vulnerability and adaptive capacity) of ecosystems. ${ }^{26}$ The inherent variability of the effects of climate change on freshwater resources is prone to increase uncertainties and stress, and even to make a water regime vulnerable to conflict among the users of water. It is notable in this respect that water management systems are already under stress in many parts of the world due to an increasing demand for fresh water, ${ }^{27}$ and that climate change will add further stress in these circumstances. ${ }^{28}$

In general, climate change strengthens the fact that freshwater resources are commonly unevenly and irregularly distributed. In addition, climate change results in increased uncertainties, stress and potential for conflicts in water management. Water security risks in the form of floods, droughts, pollution and even terrorism are bound to increase in almost all parts of the world. These risks, stemming largely from climate change, are magnified by the related uncertainties. Climate change inevitably influences the sources of water conflicts: problems in water quantity and quality; conflicts between water users; and the consequences of water-related extreme events (the

\footnotetext{
24 See eg Jiménez Cisneros et al "Freshwater Resources".

25 Petersen-Perlman et al 2012 JCWRE 4.

26 See, for instance, De Stefano et al Mapping the Resilience; and Kernan, Batterbee and Moss Climate Change Impacts.

27 For instance, the conflicts in Middle East and North Africa are partly fuelled by the availability and use of fresh water. For a good account of the situation, see eg Gleick 2014 Wea Climate Soc 331. See, for instance, Pohl et al Rise of Hydro-diplomacy.
} 
number and severity of which will increase due to climate change). Pollution, flooding or a general scarcity of water, or difficulties in realising the different uses of water resources due to climate change may create tensions and spark a conflict between states or other actors, even if no party could be directly accused of precipitating the situation. ${ }^{29}$ It appears clear that environmental changes are likely to worsen existing and trigger new social and political conflicts over water. This is especially true in the current circumstances of increased political and economic value of water ${ }^{30}$ and when the climate-induced scarcity of water makes many of the current uses of water questionable. ${ }^{31}$

\section{$4 \quad$ Accounting for the risks posed by climate change to water security: governance challenges}

The current water crisis visible in many parts of the world, be it due to climate change alone or partly in addition to other factors, has been described by many as a crisis of governance. ${ }^{32}$ Solving this crisis requires responses to the inherent risks and challenges and the introduction of good water governance at all levels. The existence of climate change necessitates that water governance and management be prepared to address both short-term and long-term issues relating to natural climate variability and shifts imposed by climate change. ${ }^{33}$ In addition, relevant risks and potential conflicts need to be recognised at all levels.

Effective water governance in the area of climate change and in response to the looming threat of water insecurity must be based on appropriate legal and regulatory management of water resources and the problems that affect/contribute to water insecurity. It has been said that uncertainty ${ }^{34}$ about the timing, scale, intensity, and character of the probable impacts is the most significant water governance challenge presented by climate change.

29 Eckstein has pointed out how the water-related impacts of climate change can lead to an increased risk of conflicts among nations and people. Accordingly, reduced precipitation and water flows could enhance droughts and scarcity, thereby diminishing agricultural productivity, endangering public health, impacting on migration and settlement patterns, and placing considerable strain on the livelihoods and social well-being of people. Similarly, increased rain events and water flows could produce destructive floods that risk human lives, raze crops and habitats, force human relocation, and damage the social fabric of communities. Eckstein 2010 Wis Int'l LJ 426.

$30 \quad$ Tir and Stinnett $2012 \mathrm{~J}$ Peace Res 213.

$31 \quad$ See Tir and Stinnett $2012 \mathrm{~J}$ Peace Res 214.

32 Wouters Water Security 13.

33 Hill Clarvis et al 2014 Environ Sci Policy 62.

34 The uncertainties may be both exogenous or endogenous within a single regime. See Drieschova and Fischhendler Toolkit of Mechanisms. 
Consequently, the development and implementation of policies, laws, and management frameworks should arguably shift from traditional paradigms that attempt to reduce uncertainty to ones that acknowledge change and commit to continuous learning. ${ }^{35}$

The sustainable use of water ${ }^{36}$ (for the purpose of both ecosystem viability and human utilization) is another key issue for reducing climate-induced water insecurity. This can be achieved by better controlling the demand and availability of water, for instance by the promotion of efficient water use and the reduction of pollution. Sustainable use may be regarded as part of the general water law principle of equitable utilisation, ${ }^{37}$ covering past, present, and foreseeable future human needs and the avoidance of unnecessary harm, for instance. Often related to the concept of sustainable use is the principle of the prioritization of water uses. ${ }^{38}$ It seeks, where possible, to establish an order of priority for different water uses with the aim of reducing conflicts between competing uses.

The role of strengthened governance and institutions is important in effectively dealing with the impacts of climate change on freshwater resources. Concrete means of information-sharing and capacitydevelopment help in developing capacity to respond to changes and prevent conflicts. Every effort should be made to prevent the rate of change from exceeding the institutional and governance capacity to respond to it. Policymakers should remain open and responsive to new problems and be aware of the latest developments and climate scenarios.

In general, what freshwater governance is in need of in the current situation is a certain degree of institutional and normative flexibility. This would entail instruments and institutions that can adapt to changes and manage the level of uncertainty associated with the impacts of climate change. The other side of this coin is naturally the resultant tension with the notion that a functional system of governance must foster stability and (legal) certainty. It has been argued that appropriate process could aid in addressing this tension. As a result, the governance process would incorporate elements of good governance through the promotion of legitimacy and inclusiveness of public

\footnotetext{
35 Sanchez and Roberts Transboundary Water Governance 149.

36 Article 5 of the Convention on the Law of Non-navigational Uses of International Watercourses (1997). See, for instance, Epiney 2003 ZaöRV.

37 Article 5 of the Convention on the Law of Non-navigational Uses of International Watercourses (1997). See, for instance, Kaya Equitable Utilization.

38 Articles 5-7, 10 of the Convention on the Law of Non-navigational Uses of International Watercourses (1997). See, for instance, Winkler Human Right to Water.
} 
input. ${ }^{39}$ Response measures to the impacts of climate change inevitably entail some degree of flexibility and openness. At the same time, the approach should be holistic and give recognition to long-term perspectives to prevent the governance regime from developing into a series of impulsive twists that seek to respond to every new projected impact and scenario that climate change science and stakeholders produce. Overall, the setting is challenging.

\section{The need for the adaptive governance of fresh water in the face of climate change: theory and practice}

Adaptation to climate change may be defined as:

An adjustment in ecological, social or economic systems in response to observed or expected changes in climatic stimuli and their effects and impacts in order to alleviate adverse impacts of change or take advantage of new opportunities. Adaptation can involve both building adaptive capacity thereby increasing the ability of individuals, groups or organisations to adapt to changes, and implementing adaptation decisions, i.e. transforming that capacity into action. Both dimensions of adaptation can be implemented in preparation for or in response to impacts generated by a changing climate. ${ }^{40}$

The different types and levels of uncertainties presented by climate change as the often most pressing water governance challenge arguably require a shift from traditional attempts to reduce uncertainty to adaptation to the new circumstances. However, the shift in policy-making will not come easily. It has been contended that admitting uncertainty may weaken the likelihood of reaching agreement, and given the difficulties of reaching agreement in the first place, adapting regulatory instruments to changed circumstances is incredibly difficult. ${ }^{41}$ Nevertheless, it can be expected that climate change will become such a crosscutting issue in all fields of life and regulation that adapting to its impacts and its inherent uncertainties will be an increasingly legitimate approach in the future. This is even more so since mitigation of climate change will take a long time to achieve results; adaptation will be both necessary and imperative. ${ }^{42}$ It may also be the case in many regions that adaptation measures taken in time will be a more cost-effective option than waiting for the effects of the mitigation measures.

Within freshwater governance, climate change impacts on the water systems are not the sole category of change that needs to be accounted

Cosens, Gunderson and Chaffin 2014 Idaho L Rev 12-13.

Adger, Arnell and Tompkins 2005 Global Environmental Change 78.

Green, Cosens and Garmestani 2013 Ecology and Society 24.

42 See, for instance, Bruch and Troell 2011 Water International; UNECE Guidance on Water. 
for. To remain effective, the regulation has to take into account and respond inter alia to seasonal and inter-annual variations in the natural flow rate, population growth, economic development and overall resource volume..$^{43}$ In addition, the posited uncertainty may involve the benefits of adaptation and impacts not only on ecosystems but also on social and economic systems. Thus, the impacts of climate change are one piece of the broader puzzle which forms the regulatory environment of freshwater systems.

In general, to ensure that they have the capacity to meet the challenges of climate change, water governance regimes should have a broad mandate, allowing them to adopt adaptive measures in response to changing conditions. The adaptive capacity of freshwater basins is the key for their survival in the context of changing climate ${ }^{44}$ Koeppe ${ }^{45}$ has identified the following enabling factors for adaptive capacity within water governance regimes: adaptive and reliable legal frameworks for regulation; flexible forums for communication, discussion and decision-making; regular reliable data and information sources about climate change and flow variability; multilevel governance of climate change adaptation - clear responsibilities at the transboundary and national levels; and learning capacity.

\subsection{Adaptive management and governance}

The concepts of "adaptive governance" and "adaptive management" have been used to describe the necessary policy direction to ensure that governance frameworks stay in pace with the effects of climate change. ${ }^{46}$ In general, the governance of adaptation has been said to have a twofold objective of: 1) overcoming the impediments to taking adaptation measures; and 2) enhancing society's capacity to remain adaptive to change after initial adaptation measures have been taken. ${ }^{47}$ Thus, it could be thought that adaptation governance seeks not only to put in place and implement adaptation measures but also, to some degree, to more permanently change society and its adaptive capacity more generally. Consequently,

$43 \quad$ Kistin and Ashton 2008 Int J Water Resour Dev 385-386.

44 For a list of examples of mechanisms that have been employed internationally to deal with adaptation and change in the governance of transboundary water resources, see Hearns and Paisley 2013 GGUELJ 279-281. For a list of mechanisms that transboundary watershed countries should consider incorporating into existing treaties to allow for flexibility in the face of change, see Cooley and Gleick 2011 Hydrolog Sci $J 717$.

45 Koeppel Transboundary Water Management 170.

46 See, generally, eg Dietz, Ostrom and Stern 2003 Science; Bruch "Adaptive Water Management" 91-92.

47 Rijke Delivering Change 3. 
when assessing adaptation governance we need to take a broader view and look beyond the immediate measures taken and effects achieved.

Adaptive management is a well-established approach that focuses on methods such as learning by doing, social learning and scenario planning. These devices allow greater flexibility, which has been said to improve the connectivity between different processes and scales. ${ }^{48}$ The framework of adaptive management incorporates uncertainty into the policy-making process; one could speak about "the institutionalization of the trial and error process" within the context of legal frameworks, institutional mandates, or management practices. ${ }^{49}$ Thus, adaptive management refers to a systematic process for continually improving management policies and practices by learning from the outcomes of the management strategies already implemented. ${ }^{50}$ Adaptive management must, therefore, be both anticipatory and reactive. ${ }^{51}$ Change, or an attempt to reduce uncertainties, and continuous learning are the keystones of adaptive management.

While the concepts of adaptive governance and adaptive management are often used interchangeably, one could make a distinction between the two. The notion of adaptive governance is often more administratively oriented, focusing on the structures of governance. It has been said that adaptive governance "relies on polycentric institutional arrangements that operate at multiple scales and balance between centralized and decentralized control".52 Furthermore, the adaptive governance framework is often operationalised through so-called adaptive co-management, whereby the dynamic learning characteristic of adaptive management is combined with the multilevel linkage characteristic of co-management. This refers to the sharing of management power and responsibility, which may involve multiple and often polycentric institutional and organisational linkages among user groups or communities, government agencies, and nongovernmental organisations. ${ }^{53}$ This may happen through self-organisation, as a result of learning and interaction. However, it has been pointed out that the self-organisation needs to be enabled by flexible institutional arrangements that encourage reflection, innovative responses, and some

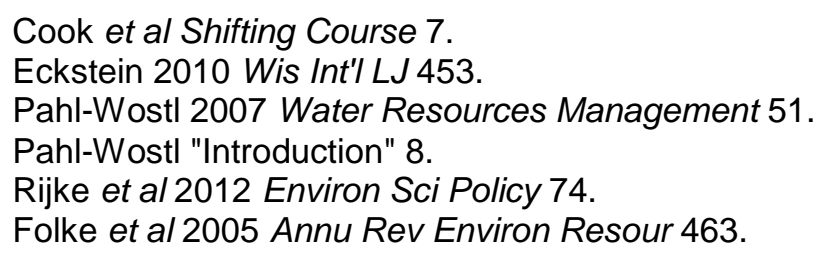


redundancy. ${ }^{54}$ As a result, the goal of adaptive capacity of the governing system can (potentially) be reached. ${ }^{55}$

The usefulness of adaptive management or governance within the freshwater context was recognised in the latest (2014) report of the IPCC, which acknowledged that an adaptive approach to water management can address uncertainty due to climate change. ${ }^{56}$ The concept of adaptive water management could, thus, simply be defined as "the management of water resources under conditions of inherent uncertainty". ${ }^{57}$ For the purposes of the present paper, the concepts of adaptive governance and adaptive management are used to refer to what is essentially the same phenomenon, despite the slight differences in the connotations of the two terms.

\subsection{Practical application}

What are the concrete regulatory requirements or means through which adaptive management or governance can generally be realised under freshwater management, to respond to the impacts of climate change and to reduce water insecurity? It has been assessed, on a general level, that most water governance frameworks are not structured in such a way as to be able to address the increased level of variability, uncertainty, and potentially irreversible changes that are posed by climate variability and change..$^{58}$ Furthermore, arguably, most applicable legal provisions are not specifically contextualized or enforced for adaptive purposes. ${ }^{59}$ Consequently, applying and enforcing these existing provisions takes on a new sense of urgency in the light of the projected impacts of climate change. ${ }^{60}$ It could be argued that adaptation to climate change has not yet reached a sufficiently high status in most legal systems, be they national, regional or international. On the other hand, an increasing number of freshwater regimes at all levels have developed climate change adaptation strategies or similar soft law instruments as the first step in designing responses to the need to adapt to the impacts of climate change at the basin level. These kinds of developments should be further encouraged.

\footnotetext{
$54 \quad$ Rijke et al 2012 Environ Sci Policy 74.

55 See Cook et al Shifting Course 7.

56 Jiménez Cisneros et al "Freshwater Resources" 232.

57 Edwards et al "Transforming Water Management Institutions" 291.

58 Bruch and Troell 2011 Water International 830.

59 Bruch and Troell 2011 Water International 830. It is difficult to make "static" legal provisions that lack flexibility responsive to changing circumstances.

60 Bruch and Troell 2011 Water International 830.
} 
It has become clear by now that flexibility, be it institutional or normative, is essential. Governance institutions, methods and instruments should be responsive to new information, different kinds of uncertainties etc. As regards water management institutions, it is important that they adopt an adaptable management mandate and structure. The key is the willingness, competence and capacity of the institution to recognise and respond to changing circumstances. An adaptable governing institution shows flexibility by quickly responding to new information and being ready to adjust to relevant activities and objectives. ${ }^{61}$ By way of an example, the flexible mandate of the International Commission for the Protection of the Rhine ${ }^{62}$ has proved very useful. The Commission is required to be competent in all matters with which the riparian states jointly charge it. This has enabled parties to empower the Commission to manage the rehabilitation of the Rhine ecosystem and to deal with flood problems. ${ }^{63}$

An example of a concrete, flexible regulatory tool for freshwater management is the use of flexible water allocation strategies. They use percentage shares or a similar mechanism to determine the allocations, instead of a fixed allocation that requires a specific nominal volume of water to be delivered from a dam, for instance. ${ }^{64}$ The flexible allocation mechanism is naturally more suitable for adaptive water management since it addresses climate-induced changes in water availability as well as other uncertainties and changing conditions.

At the same time that flexible adaptation mechanisms are applied, it is crucial to strike the right balance between legal certainty and flexibility to provide for rules that can deal with change without becoming arbitrary or uncertain. ${ }^{65} \mathrm{It}$ is often equally important that the need to introduce changes to the objectives, rights and obligations included in the water governance mechanisms and regulatory instruments is periodically assessed. This would enable the regime to respond timeously to new scientific knowledge

\footnotetext{
61 Eckstein 2010 Wis Int'I LJ 453.

62 A cooperative organ of nine states and regions in the Rhine watershed, in Central Europe, implementing the Convention on the Protection of the Rhine (1999) and European water law.

63 Frijters and Leentvaar Rhine Case Study 8.

64 It is also possible to combine fixed allocations with percentage allocations to provide a somewhat more predictable and flexible water allocation mechanism. Particular principles of water allocation, such as equity, rational use, limitations on harm, and sustainability may be applied to this. 
and changing hydrological, social or climatic conditions, in line with the adaptive approach. ${ }^{66}$

Flexibility or adaptability are also important in enabling learning in policy making and implementation. This can be realised through the usage of assessments and monitoring results in an iterative process of decisionmaking, ${ }^{67}$ but also through the active involvement of different stakeholders and the utilization of the information they have to provide for the process. ${ }^{68}$ Broad participation in decision making also gives important legitimacy to the governance process and its outcomes.

Concrete means by which policy-makers may address many of the abovementioned requirements for effective freshwater management based on adaptive governance are to prepare climate change impact assessments, vulnerability assessments and strategies for adapting water management to climate change. It is not always necessary to re-build the whole regulatory framework to be able to address emerging issues such as increased flow variability due to climate change, but the situation can be managed through the elaboration of policies or strategies such as flood or drought management plans or adaptation strategies. ${ }^{69}$ In general, better adaptation policies are needed to reflect the vulnerabilities, capacities, needs and priorities of both societies and ecosystems in the face of climate change.

Overall, monitoring, information management and effective communication are important components of any adaptive management approach. The governance institutions need to be continually aware of the changes that are taking place over time, as well as of the responses stemming from past decisions. ${ }^{70}$ Again, it is important that the institutions and governance

66 See Fischhendler 2004 Water Policy.

67 Keessen and Van Rijswick 2012 Utrecht $L$ Rev 40-41. An iterative or cyclical approach to planning and governance emphasises the use of monitoring and evaluation to inform future operations. This allows an institution or a decision-maker to absorb new learning and knowledge into existing plans and account for both social and institutional learning. Cook et al Shifting Course 15.

68 Especially where flexibility and quick responses in emergency situations are required, having local stakeholders involved in the decision-making is likely to produce more effective implementation of the chosen adaptation measures. Bruch and Troell 2011 Water International 831.

69 Koeppel Transboundary Water Management 188.

70 Edwards et al "Transforming Water Management Institutions" 292. Extreme weather events resulting from climate change provide an example. The events should be analyzed with a view to identifying options for preventing such events and limiting their impact in the future as well as for improving preparedness. See Koeppel Transboundary Water Management 189. This would amount to a significant learning experience for all relevant parties. 
instruments should be flexibly and dynamically designed to allow them to react to unexpected changes and circumstances. This is in line with a reactive adaptation approach, in contrast to proactive adaptation, under which timing of action is different (changes are anticipated). ${ }^{71}$ In relation to this, it is important to bear in mind that even without climate change, the water levels and flows in rivers and lakes fluctuate. This is a natural phenomenon. Water regulation needs to take these changes into account, especially in times of climatic change-induced flow variability. In practice, this means rules and mechanisms by which policy-makers and other actors prepare for droughts and floods. To account for anticipated changes in the quantity of water, a regulatory instrument may allow for diminished water deliveries in exceptional circumstances. Other kinds of escape-clause mechanisms may also be introduced, often accompanied by a deficit mechanism which allows the upstream riparian to reduce its water flow, while compelling it to return the water at a later time, when natural circumstances permit. ${ }^{72}$ This is an example of a response strategy for extreme events, which is built on flexibility and on an adaptive management approach.

It has been argued that moving from the current system to a more adaptive form of governance will require legal authorities/policy makers to form appropriate networks for adaptive responses and to develop bridging organisations where gaps occur, and authority for collaborative processes to establish goals for adaptive management. ${ }^{73}$ This will require effective involvement of and cooperation between and with different levels of administrators, the scientific community, other stakeholders and the public. In addition, adequate financial and human resources (experience and expertise), as well as technological and informational resources, effectively and efficiently deployed, allow an institution to react quickly to an event, allocate or use resources more flexibly, or better prepare for unpredictable hydrological situations.

It has been assessed that the application of adaptive management requires capabilities different from traditional forms of water management. ${ }^{74}$ This is the case especially when it comes to creating forms of collaboration between water policy-makers and stakeholders, the relation between science and policy, the importance of participatory learning processes,

71 See, for instance, Berrang-Ford, Ford and Paterson 2011 Global Environmental Change.

72 See eg Fischhendler 2004 Water Policy.

73 Cosens et al 2014 Sustainability 2346.

74 See eg Huntjens et al 2011 Environ Policy Gov 148. 
dealing with uncertainty, and assessing a wide variety of possible measures and future scenarios. ${ }^{75}$ All parties must adopt a new approach and remain committed to the learning processes and their outcomes. Policy-makers must also be prepared to simply tolerate a certain degree of unavoidable uncertainty regarding their governance object and environment.

The adaptive management or governance approach has certain implications for water security. First, it implies a greater degree of polycentrism and multi-levelness in governance, where a broader range of actors and stakeholders plays a role in policy-making. ${ }^{76}$ This is a desirable by-product of the emphasis laid on learning processes, co-management and dealing with inherent uncertainties. Secondly, adaptive water management or governance works towards reducing water insecurity by paying increasing attention to issues of social power in negotiating conflicts. The governance mechanisms adopted are apt to mitigate trade-offs and resolve conflicts between users, sectors and nation-states. ${ }^{77}$ In other words, comanagement practices and the broad participation of different actors tend to mitigate conflict situations or prevent them from arising in the first place.

The concept of hydrosolidarity ${ }^{78}$ has been much discussed in recent years, especially in the context of transboundary watercourses. It reflects an innovative approach that embraces collective action, interdependence, and shared responsibility. Applied in the present context, the idea of hydrosolidarity could be used to present the challenges posed by climate change to water governance and security as primarily an opportunity for new forms of cooperation - instead of viewing the issues exclusively as security concerns.

Indeed, it has been posited that the global water security problem and discussion of it call for a radical reframing of the prevailing dialogue. The real challenges are, arguably, the need for innovative thinking about the issue, including the investigation of new legal rules and management regimes. ${ }^{79}$ The effective and innovative application of adaptive water governance could provide an answer. In a transboundary river basin there

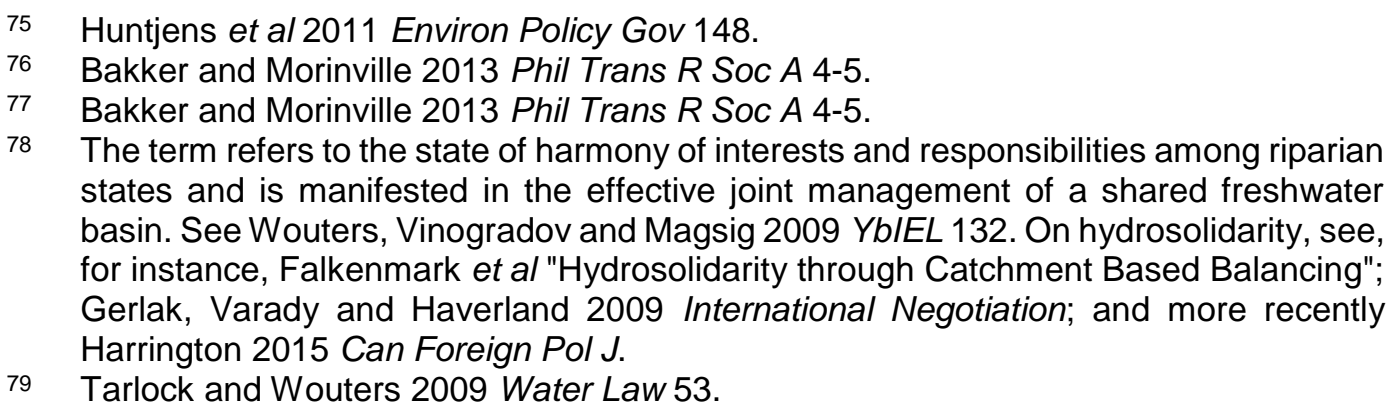
states and is manifested in the effective joint management of a shared freshwater basin. See Wouters, Vinogradov and Magsig 2009 YbIEL 132. On hydrosolidarity, see, for instance, Falkenmark et al "Hydrosolidarity through Catchment Based Balancing"; Gerlak, Varady and Haverland 2009 International Negotiation; and more recently Harrington 2015 Can Foreign Pol J.

79 Tarlock and Wouters 2009 Water Law 53. 
is an inherent interdependence among riparians: they must respond not only to the potential impacts of climate change within their own boundaries but also to potential stresses caused by spill-overs from co-riparian nations. Arguably, this calls attention to a need to move beyond considerations of adaptive capacity as a national or sub-national level phenomena and points to the value of an improved understanding of transboundary adaptive capacity. ${ }^{80}$

\section{$6 \quad$ Concluding remarks}

It has become clear that water is the main medium through which the effects of climate change will be observed and felt. Climate change will ultimately come down to changes in the timing, quantity and quality of water resources. Climate change will exacerbate the unevenness and irregularity of the distribution of water within and among states. It will result in increased uncertainties, stress and potential for conflict within water management. Consequently, water security has already become an issue in this respect, and it is important to deal with the resultant risks. In these circumstances, water governance needs to be responsive to conditions of great complexity and uncertainty.

This paper has argued that the concept of adaptive governance needs to be integrated into all water regulation in order to ensure the availability of and access to safe water resources and to prevent conflicts within freshwater management. It is not useful to concentrate solely on efforts to reduce the negative impacts of climate change and the related uncertainties, but it is at least equally important to acknowledge change and to seek for ways to learn from and adapt to it. Water governance institutions and policy-makers must be continually aware of the changes that occur over time, as well as of the responses stemming from past decisions.

What the application of adaptive governance requires is a certain degree of institutional and normative flexibility, and instruments and institutions that can respond and adapt to changes and manage the level of uncertainty associated with the impacts of climate change. The governance institutions, methods and instruments should be responsive to new information and different kinds of uncertainties while reflecting the vulnerabilities, capacities, needs and priorities of both societies and ecosystems in the context of climate change. However, this flexibility needs to be carefully balanced with

80 Milman et al Adaptive Capacity of Transboundary Basins 1. 
the need to have a system of governance that fosters stability and (legal) certainty.

The governance challenges posed by climate change to freshwater management will put the water systems and their management regimes to the test. Resilience and adaptive capacity will become key qualities in the process and, at the same time, the linkages to water security will be strengthened.

\section{Bibliography}

\section{Literature}

Adger, Arnell and Tompkins 2005 Global Environmental Change

Adger WN, Arnell NW and Tompkins EL "Successful Adaptation to Climate Change Across Scales" 2005 Global Environmental Change 77-86

Bakker and Morinville 2013 Phil Trans R Soc A

Bakker $\mathrm{K}$ and Morinville $\mathrm{C}$ "The Governance Dimensions of Water Security: A Review" 2013 Phil Trans R Soc A 1-18

Berrang-Ford, Ford and Paterson 2011 Global Environmental Change Berrang-Ford L, Ford JD and Paterson $\mathrm{J}$ "Are We Adapting to Climate Change?" 2011 Global Environmental Change 25-33

Bruch "Adaptive Water Management"

Bruch C "Adaptive Water Management: Strengthening Laws and Institutions to Cope with Uncertainty" in Biswas AK and Tortajada C (eds) Water Management in 2020 and Beyond (Springer Berlin 2009) 89-113

Bruch and Troell 2011 Water International

Bruch $\mathrm{C}$ and Troell $\mathrm{J}$ "Legalizing Adaptation: Water Law in a Changing Climate" 2011 Water International 828-845

Cook and Bakker 2012 Global Environmental Change

Cook J and Bakker K "Water Security: Debating an Emerging Paradigm" 2012 Global Environmental Change 94-102

Cook et al Shifting Course

Cook J et al Shifting Course: Climate Adaptation for Water Management Institutions (World Wildlife Fund Washington DC 2011) 
Cooley and Gleick 2011 Hydrolog Sci J

Cooley $\mathrm{H}$ and Gleick PH "Climate-proofing Transboundary Water Agreements" 2011 Hydrolog Sci J 711-718

Cosens, Gunderson and Chaffin 2014 Idaho L Rev

Cosens B, Gunderson L and Chaffin B "The Adaptive Water Governance Project: Assessing Law, Resilience and Governance in Regional Socioecological Water Systems Facing a Changing Climate. Introduction to the NREL Edition of the Idaho Law Review" 2014 Idaho L Rev 1-27

Cosens et al 2014 Sustainability

Cosens B et al "Identifying Legal, Ecological and Governance Obstacles, and Opportunities for Adapting to Climate Change" 2014 Sustainability 2338-2356

De Stefano et al Mapping the Resilience

De Stafano L et al Mapping the Resilience of International River Basins to Future Climate Change-Induced Water Variability (World Bank Washington DC 2010)

Dietz, Ostrom and Stern 2003 Science

Dietz T, Ostrom E and Stern PC "The Struggle to Govern the Commons" 2003 Science 1907-1912

Drieschova and Fischhendler Toolkit of Mechanisms

Drieschova A and Fischhendler I A Toolkit of Mechanisms to Reduce Uncertainty in International Water Treaties (Hebrew University of Jerusalem Jerusalem 2011)

Eckstein 2010 Wis Int'I LJ

Eckstein G "Water Scarcity, Conflict, and Security in a Climate Change World: Challenges and Opportunities for International Law and Policy" 2010 Wis Int'l LJ 409-461

Edwards et al "Transforming Water Management Institutions"

Edwards $\mathrm{H}$ et al "Transforming Water Management Institutions to Deal with Change" in UN-Water Managing Water under Uncertainty and Risk (UNESCO Paris 2012) 289-308

Epiney 2003 ZaöRV

Epiney A "Sustainable Use of Freshwater Resources" 2003 ZaöRV 377-396 
Falkenmark et al "Hydrosolidarity through Catchment Based Balancing"

Falkenmark $\mathrm{M}$ et al "Hydrosolidarity through Catchment Based Balancing of Human Security and Ecological Security" Unpublished contribution delivered at the Virtual World Water Forum (20 March 2003 Kyoto)

Fischhendler 2004 Water Policy

Fischhendler I "Legal and Institutional Adaptation to Climate Uncertainty: A Study of International Rivers" 2004 Water Policy 281-302

Folke et al 2005 Annu Rev Environ Resour

Folke C et al "Adaptive Governance of Scio-ecological Systems" 2005 Annu Rev Environ Resour 441-473

Frijters and Leentvaar Rhine Case Study

Frijters ID and Leentvaar J Rhine Case Study (UNESCO-IHP Paris 2003)

Gerlak, Varady and Haverland 2009 International Negotiation

Gerlak AK, Varady RG and Haverland AC "Hydrosolidarity and International Water Governance" 2009 International Negotiation 311-328

Gleick 2014 Wea Climate Soc

Gleick PH "Water, Drought, Climate Change, and Conflict in Syria" 2014 Wea Climate Soc 331-340

Green, Cosens and Garmestani 2013 Ecology and Society

Green OO, Cosens BA and Garmestani AS "Resilience in Transboundary Water Governance: The Okavango River Basin" 2013 Ecology and Society 23-37

Harrington 2015 Can Foreign Pol J

Harrington C "Toward a Critical Water Security: Hydrosolidarity and Emancipation" 2015 Can Foreign Pol J 28-44

Hearns and Paisley 2013 GGUELJ

Hearns $G$ and Paisley RK "Lawyers Write Treaties, Engineers Build Dikes, Gods of Weather Ignore Both: Making Transboundary Waters Agreements Relevant, Flexible, and Resilient in a Time of Global Climate Change" 2013 GGUELJ 259-294

Hill Clarvis et al 2014 Environ Sci Policy

Hill Clarvis $\mathrm{M}$ et al "Governing and Managing Water Resources Under Changing Hydro-climatic Contexts: The Case of the Upper Rhone Basin" 2014 Environ Sci Policy 56-67 
Huntjens et al 2011 Environ Policy Gov

Huntjens $\mathrm{P}$ et al "Adaptive Water Management and Policy Learning in a Changing Climate: A Formal Comparative Analysis of Eight Water Management Regimes in Europe, Africa and Asia" 2011 Environ Policy Gov 145-163

IPCC Climate Change 2014

IPCC Climate Change 2014: Synthesis Report. Contribution of Working Groups I, II and III to the Fifth Assessment Report of the Intergovernmental Panel on Climate Change (IPCC Geneva 2014)

Jiménez Cisneros et al "Freshwater Resources"

Jiménez Cisneros BE et al "Freshwater Resources" in Field CB and Barros VR (eds) Climate Change 2014: Impacts, Adaptation, and Vulnerability. Part A: Global and Sectoral Aspects. Contribution of Working Group II to the Fifth Assessment Report of the Intergovernmental Panel on Climate Change (Cambridge University Press, Cambridge 2014) 229-269

Kaya Equitable Utilization

Kaya I Equitable Utilization. The Law of Non-navigational Uses of International Watercourses (Ashgate Aldershot 2003)

Keessen and Van Rijswick 2012 Utrecht L Rev

Keessen AM and Van Rijswick HFMW "Adaptation to Climate Change in European Water Law and Policy" 2012 Utrecht L Rev 38-50

Kernan, Batterbee and Moss Climate Change Impacts

Kernan M, Batterbee RW and Moss B Climate Change Impacts on Freshwater Ecosystems (Wiley Blackwell Chichester 2010)

Kistin and Ashton 2008 Int $J$ Water Resour Dev

Kistin EJ and Ashton PJ "Adapting to Change in Transboundary Rivers: An Analysis of Treaty Flexibility on the Orange-Senqu River Basin" 2008 Int J Water Resour Dev 385-400

Koeppel Transboundary Water Management

Koeppel S Transboundary Water Management and Climate Change Adaptation: A Comparative Study of Four European River Basins (PhDdissertation Central European University 2014)

Lautze and Manthrithilake 2012 Natural Resources Forum

Lautze $\mathrm{J}$ and Manthrithilake $\mathrm{H}$ "Water Security: Old Concepts, New Package, What Value?" 2012 Natural Resources Forum 76-87 
Mason and Calow Water Security

Mason N and Calow R Water Security: From Abstract Concept to Meaningful Metrics. An Initial Overview of Options (Overseas Development Institute London 2012)

McCaffrey 2003 Natural Resources Forum

McCaffrey SC "The Need for Flexibility in Freshwater Treaty Regimes" 2003 Natural Resources Forum 156-162

Milman et al Adaptive Capacity of Transboundary Basins

Milman A et al Adaptive Capacity of Transboundary Basins in the Mediterranean, the Middle East and the Sahel (Tyndall Centre Norwich 2011)

Mirumachi Transboundary Water Security

Mirumachi N Transboundary Water Security: Reviewing the Importance of National Regulatory and Accountability Capacities in International Transboundary River Basins (Department of Geography, King's College London 2013)

OHCHR Understanding Human Rights and Climate Change

OHCHR Understanding Human Rights and Climate Change: Submission of the Office of the High Commissioner for Human Rights to the 21st Conference of the Parties to the United Nations Framework Convention on Climate Change (OHCHR Geneva 2015)

OECD Water and Climate Change Adaptation

OECD Water and Climate Change Adaptation: Policies to Navigate Uncharted Waters (OECD Paris 2013)

Orellana et al Climate Change

Orellana MA et al Climate Change in the Work of the Committee on Economic, Social and Cultural Rights (Friedrich-Ebert-Stiftung Geneva 2010)

Pahl-Wostl 2007 Water Resources Management

Pahl-Wostl C "Transitions Towards Adaptive Management of Water Facing Climate and Global Change" 2007 Water Resources Management 49-62

Pahl-Wostl "Introduction"

Pahl-Wostl C "Introduction" in Pahl-Wostl C, Kabat P and Möltgen J (eds) Adaptive and Integrated Water Management: Coping with Complexity and Uncertainty (Springer Berlin 2008) 2-22 
Petersen-Perlman et al 2012 JCWRE

Petersen-Perlman JD et al "Case Studies on Water Security: Analysis of System Complexity and the Role of Institutions" 2012 JCWRE 4-12

Pohl et al Rise of Hydro-diplomacy

Pohl B et al The Rise of Hydro-diplomacy. Strengthening of Foreign Policy for Transboundary Waters (Adelphi Berlin 2014)

Rijke Delivering Change

Rijke JS Delivering Change: Towards Fit-for-purpose Governance of Adaptation to Flooding and Drought (PhD-dissertation Delft University of Technology and the UNESCO-IHE Institute for Water Education 2014)

Rijke et al 2012 Environ Sci Policy

Rijke JS et al "Fit-for-purpose Governance: A Framework to Make Adaptive Governance Operational" 2012 Environ Sci Policy 73-84

Sadoff and Muller Water Management

Sadoff C and Muller M Water Management, Water Security and Climate Change Adaptation: Early Impacts and Essential Responses (Global Water Partnership Stockholm 2009)

Sanchez and Roberts Transboundary Water Governance

Sanchez JC and Roberts J (eds) Transboundary Water Governance: Adaptation to Climate Change (IUCN Gland 2014)

Tarlock and Wouters 2009 Water Law

Tarlock D and Wouters P "Reframing the Water Security Dialogue" 2009 Water Law 53-60

Tir and Stinnett 2012 J Peace Res

Tir J and Stinnett D "Weathering Climate Change: Can Institutions Mitigate International Water Conflict?" 2012 J Peace Res 211-225

UNECE Guidance on Water

UNECE Guidance on Water and Adaptation to Climate Change (UNECE Geneva 2009)

UN Water Water Security

UN Water Water Security and the Global Water Agenda (United Nations University Hamilton 2013) 
Winkler Human Right to Water

Winkler IT The Human Right to Water: Significance, Legal Status and Implications for Water Allocation (Hart Oxford 2012)

Wouters Water Security

Wouters P Water Security: Global, Regional and Local Challenges (Institute for Public Policy Research London 2010)

Wouters, Vinogradov and Magsig 2009 YblEL

Wouters P, Vinogradov S and Magsig B-O "Water Security, Hydrosolidarity, and International Law: A River Runs Through It..." 2009 YbIEL 97-134

\section{International instruments}

Convention on the Law of Non-navigational Uses of International Watercourses (1997)

Convention on the Protection of the Rhine (1999)

International Covenant on Economic, Social and Cultural Rights (1967)

Kyoto Protocol to the United Nations Framework Convention on Climate Change (1997)

Ministerial Declaration of The Hague on Water Security in the 21st Century (2000)

Paris Agreement under the United Nations Framework Convention on Climate Change (2015)

The Human Right to Water and Sanitation GA Res 64/292, UN Doc A/RES/64/292 (2010)

United Nations Framework Convention on Climate Change (1992)

\section{Internet sources}

UN 2014 http://unfccc.int/adaptation/items/4159.php UN 2014 Adaptation http://unfccc.int/adaptation/items/4159.php accessed 11 December 2016 


\section{List of Abbreviations}

Annu Rev Environ Resour

Can Foreign Pol J

Environ Policy Gov

Environ Sci Policy

GGUELJ

Hydrolog Sci J

Idaho L Rev

Int J Water Resour Dev

IPCC

IUCN

J Peace Res

JCWRE

OECD

$\mathrm{OHCHR}$

Phil Trans R Soc A

UN

UNECE

Utrecht L Rev

Wea Climate Soc

Wis. Int'I L.J.

YbIEL

ZaöRV
Annual Review of Environment and Resources

Canadian Foreign Policy Journal

Environmental Policy and Governance

Environmental Science and Policy

Golden Gate University Environmental Law Journal

Hydrological Sciences Journal

Idaho Law Review

International Journal of Water Resources

Development

Intergovernmental Panel on Climate

Change

International Union for Conservation of Nature and Natural Resources

Journal of Peace Research

Journal of Contemporary Water Research and Education

Organisation for Economic Co-operation and Development

Office of the High Commissioner for Human Rights

Philosophical Transactions of the Royal Society A

United Nations

United Nations Economic Commission for Europe

Utrecht Law Review

Weather, Climate, and Society

Wisconsin International Law Journal

Yearbook of International Environmental Law

Zeitschrift für ausländisches öffentliches Recht und Völkerrecht 